\title{
A META-FRONTIER APPROACH TO MEASURE PRODUCTIVITY DIFFERENCES OF DOMESTIC AND FOREIGN AFFILIATED FIRMS ${ }^{1}$
}

\author{
Halil Tunca ${ }^{1}$, Mehmet Karaçuka ${ }^{2}$, A. Nazif Çatik ${ }^{3}$ \\ Department of Economics, Ege University, 35040 Bornova / Izmir, Turkey \\ E-mails: ${ }^{1}$ halil.tunca@ege.edu.tr; ${ }^{2}$ mehmet.karacuka@ege.edu.tr (corresponding author); \\ 3a.nazif.catik@ege.edu.tr
}

Received 17 May 2011; accepted 23 December 2011

\begin{abstract}
This paper aims to evaluate the performance of foreign affiliated and domestic firms in Turkish manufacturing subsectors covering the period 1992 and 2001. Due to the heterogeneity between domestic and foreign affiliated firms in terms of technology level, we construct a meta-frontier model to measure relative efficiency and technology gap ratios (TGR's) of domestic and foreign affiliated firms. We find that technical efficiencies of foreign affiliated firms are higher than domestic firms, and display a stable pattern during the investigation period. However; technology gap ratios indicate the existence of a negative relationship between the TGR's and technical efficiency of the firms in domestic subsectors. This means that technically efficient firms are in fact using the low level of technology. However the results do not indicate any significant relationship between the technical efficiency and TGR's of foreign affiliated firms.
\end{abstract}

Keywords: productivity, manufacturing subsectors, technical efficiency, meta-frontier.

Reference to this paper should me made as follows: Tunca, H.; Karaçuka, M.; Çatik, A. N. 2013. A meta-frontier approach to measure productivity differences of domestic and foreign affiliated firms, Journal of Business Economics and Management 14(4): 651-663.

JEL Classification: C23, C51, C63, D24, D36, O33.

\section{Introduction}

An important policy recommendation for developing countries is that; they need to attract foreign capital not only to decrease the gap between savings and expenditures, but also to increase productivity levels in domestic production. In theory, local economies are expected to benefit from long lasting interactions such as labor turnovers, imita-

\footnotetext{
${ }^{1}$ This paper has been completed during a visit of Mehmet Karaçuka as a Guest Scholar at Heinrich Heine Universität Düsseldorf, Düsseldorf Institute for Competition Economics (DICE), with a scholarship from the Turkish Council of Higher Education. The author thanks both institutions for providing the opportunity to benefit from the inspiring academic surrounding at DICE.
} 
tion of the superior technology, increasing competition, and commercial ties between foreign and domestic firms (Lall 1978, 1997). However, the empirical evidence ${ }^{2}$ does not support this theory unanimously; and suggests that productivity benefits are not automatic, but local conditions influence firms' adoption of foreign technologies and skills (Blomstrom, Kokko 1998, 2003).

The productivity increases through foreign affiliated firms require a threshold level of human capital and absorptive capacity of local firms (Borenzstein et al. 1998), but even more importantly it is essential that foreign firms engage in technological activities in the local economy. However; the observations on research and development (R\&D) expenditures of transnational companies show that parent firms undertake the bulk of $\mathrm{R} \& \mathrm{D}$, and when these expenditures are located within affiliate firms, they are mostly in developed countries (UNCTAD 1999; UNCTAD 2005). For instance, only $13.5 \%$ of R\&D expenditures by United States parent companies were located in developing countries and concentrated mostly in five countries (China, Singapore, Brazil, Mexico and the Republic of Korea) in 2002 (UNCTAD 2005).

Turkish government policy has long been pro-investment in order to attract more multinational companies. Despite its competitive advantages, which come from regional location, and relatively abundant labor force; Turkey can be considered as under-performing in attracting FDI. The efforts to attract foreign direct investments have been accelerated especially since the economic crisis of 2001. Dumludag (2009) argues that institutional factors such as enforcement mechanisms, political and economic stability, transparent legal and regulatory framework, and corruption are critical factors in explaining the behavior of the foreign direct investment inflows in Turkey. In this study, given the importance of foreign capital in economic policy, we investigate the validity of basic assumption that firms with foreign capital are more efficient than domestic firms, in the context of Turkish manufacturing industries.

The previous studies regarding the efficiency analysis of the firms premise that all firms have similar inputs as the factors of production. In other words, they assume that firms have ability to access the same production technology. The interpretation of the resulting efficiency scores relies on the validity of this crucial assumption. However, recent studies argue that firms even operating in the same industry may tend to have different production frontiers in terms of available stocks of physical, human and financial capital and economic infrastructure (O'Donnell et al. 2008). Due to this heterogeneity, the use

\footnotetext{
2 The empirical evidence differs by sample and the methodologies employed for estimation. For example, Ramírez (2006) finds that foreign direct investment (FDI) has a positive effect for Latin America countries. Blomstrom et al. (1994) argue that FDI affects growth when the country is above some income level threshold. Other studies also emphasize on absorbing capacities on the host countries. Wijweera et al. (2010) find that FDI has a positive impact on economic growth only in the presence of a highly skilled labor. Balasubramanyam et al. (1996) find that openness is essential to benefit from the growth effects of FDI. However, Carkovic and Levine (2002) find that FDI does not exert a reliable, positive impact on economic growth in their panel study after controlling the endogeneity problem. Görg and Strobl (2001) also show that the results differ according to data and estimation method employed in various studies.
} 
of standard efficiency analysis techniques like DEA (Data Envelopment Analysis) or SFA (Stochastic Frontier Analysis) might lead to misleading results, as the production technologies are not identical to make an accurate comparison.

The similar type of heterogeneity has been also observed for domestic and foreign affiliated firms in Turkish manufacturing subsectors. Based on the regressions of production functions, Lenger and Taymaz (2006), and Köymen and Sayek (2009) investigated the existence of innovation and technology spillovers between domestic and foreign manufacturing firms, and find that foreign firms have different characteristics than their domestic counterparts in terms of innovativeness and ability to transfer technology from abroad. They also find that horizontal spillovers do not have any significant contribution to the technological activities of the domestic firms in Turkey.

Although the productivity of firms in Turkish manufacturing subsectors has been previously investigated by numerous studies (See, for example, Zaim and Taşkın (1997); Bayyurt and Duzu (2008); Karadağ, Önder and Deliktaş (2002, 2005); Karadă̆, Deliktaş and Önder (2004); Y1lmazkuday (2009); Önder, Deliktaş and Lenger (2003); Krueger and Tuncer (1982)), we do not find any study accounting for the heterogeneity between domestic and foreign affiliated firms. In this paper, the difference between domestic and foreign affiliated firms is considered by applying meta-frontier methodology, introduced by Battese et al. (2002). This technique allows us to assess the performance of firms by measuring the distance of a firm belonging to either domestic or foreign group from the common meta-frontier (Rao et al. 2003). Based on group and meta-distance functions, we also compute technology gap ratios to compare the relative efficiency levels of domestic and foreign manufacturing firms.

The rest of the paper is organized as follows. The next section briefly summarizes the general framework of the meta-frontier methodology used in the paper. The data are introduced in section three. Section four summarizes the empirical results obtained from the application of meta-frontier. Finally the last section concludes the paper.

\section{Methodology}

The present paper employs meta-frontier approach, developed by Battese and Rao (2002), and O'Donnell et al. (2008) to account for heterogeneity among the domestic and foreign affiliated firms. Meta-frontier technique contains the calculation of a metatechnology and frontiers of homogenous groups which represents the common and the group specific technologies.

To illustrate the general framework of the approach, we construct a model including nonnegative input $(x)$ and output $(y)$ vectors of dimension of $(N x 1)$ and $(M x 1)$ respectively. Then subsectors are classified into two groups $k=2$ as domestic and foreign, each of which are operating under a specific technology. Since the technology can be defined as a process of transforming $N$ inputs into $M$ outputs, the meta-technology set $T^{*}$ can be be considered as an envelope of all possible group technologies. 
The technology set of a group can be defined as the combination of efficient production possibilities (Battese et al. 2004).

$$
T^{k}=\left\{(x, y) \in R_{+}^{N+M} \mid x \text { can produce } y\right\},
$$

which shows the amount of $N$ inputs $x$ that can produce $M$ outputs $y$. The input and output sets associated with the technology set $T$ provide an equivalent representation of production technology.

The input set $L(y)$ is the set of all input vectors $x$ which can produce $y$. Isoquants determine the boundaries of input set. Formally,

$$
L(y)=\left\{x:(x, y) \in T, \text { for each } y \in R_{+}^{M}\right\} .
$$

Similar to input set, the output set $P(x)$ associated with a specific input vector $x$ is the set of all output vectors $y$ which can be produced using $x$.

$$
P(x)=\left\{y:(x, y) \in T, \text { for each } x \in R_{+}^{N}\right\} .
$$

The boundary of the output set is determined by the production possibility frontier covering all optimum input output combinations. Meta-frontier can be defined as a function that envelops separate group frontiers, each of which has different technology and factor levels. In other words, the meta-frontier model is considered as an envelope of all the possible group technologies. In this case meta-technology set can be written as follows (O’Donnell et al. 2008):

$$
\begin{aligned}
& T^{*}=\{(x, y): x \geq 0 \text { and } y \geq 0, \text { such that } x \text { can produce } y \text { in at least } \\
& \text { one group technology, } \left.T^{1}, T^{2}, \ldots, T^{k}\right\} .
\end{aligned}
$$

In order to satisfy convexity of the function, meta-technology is defined as the convex hull of the union of group specific technologies (Rambaldi et al. 2007),

$$
T^{*} \equiv \text { Convex Hull }\left\{T^{1} \cup T^{2} \cup \ldots . T^{k}\right\} .
$$

Since $T^{*}$ satisfies all production axioms, technical efficiency can be computed by using input and output distance functions associated with the meta-technology set. Global meta-frontier defined as an envelope of all three group-specific frontiers is illustrated in Figure 1.

Hence, technical efficiency with respect to kth group technology can be written in terms of output distance function as follows,

$$
T E^{k}=D_{0}(x, y)=\inf _{\theta}\left\{\theta>0:(y / \theta) \in P^{k}(x)\right\} .
$$

This function shows the maximum degree to which a given output vector can be increased and still within the production feasibility set. Technical efficiency with respect to the meta-frontier is defined in an analogous way.

$$
T E^{*}=D_{o}^{*}(x, y)=\inf _{\theta}\left\{\theta>0:(y / \theta) \in P^{*}(x)\right\} \text { for all } x_{t} L^{*}\left(y_{t}\right) .
$$




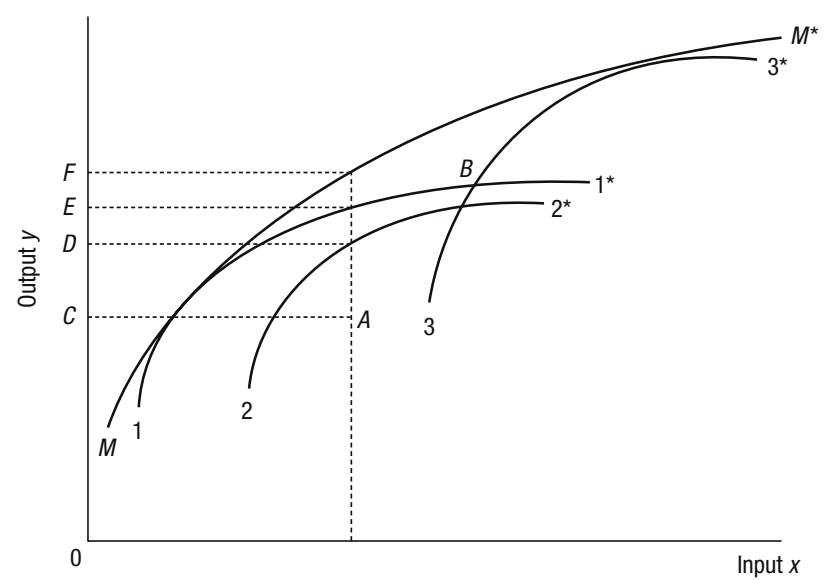

Fig. 1. Group specific frontier and meta-frontier Source: O’Donnell et al. 2008: 236.

Since the meta-frontier function covers all the group specific technology by definition, the output distance function of $k$ group frontier should be greater than or equal to the output distance function of meta-frontier.

$$
D_{0}^{k}(x, y) \geq D_{0}^{*}(x, y) .
$$

Figure 1 illustrates the difference between the calculations of technical efficiency with respect to group and meta-frontier. If we take the input-output combination represented by the point $A$, the technical efficiency with respect to group frontier 2 showing the difference between actual and potential output can be measured as $O C / O D$. On the other hand, the technical efficiency with respect to meta-frontier $M-M$ can be calculated by $O C / O F$.

Based on the technical efficiency with respect to the group frontier and the meta-frontier in (7) and (8) one can also obtain Technology Gap Ratio (TGR) which measures the gap between the group $\mathrm{k}$ technology $T^{k}$ and the meta-technology $T^{*}$ in terms of output distance functions:

$$
T G R_{o}^{k}(x, y)=\frac{D_{o}^{*}(x, y)}{D_{o}^{k}(x, y)}=\frac{T E_{o}^{*}(x, y)}{T E_{o}^{k}(x, y)} .
$$

Equation (9) indicates that the technical efficiency relative to the meta-frontier is the product of the technical efficiency relative to frontier of the specified group and the technology gap ratio (Battese et al. 2004). TGR gap ratio has values between zero and one, and this implies that for a given input vector, potential output of the group technology is a certain percentage of the potential output defined by the meta-frontier. Based on this definition, $T G R$ of point $A$ in Figure 1 would be equal to $O C / O F$. As the general framework of the model shows, the calculation of meta-frontier is based on the comparison of efficiency levels of meta-frontier and the group frontiers. These measures 
can be calculated by applying standard optimization techniques like DEA or SFA. SFA and DEA are the two most widely used methods to measure efficiency in the literature. In this paper we prefer DEA approach for two reasons. First, although it is sensitive to errors in data, it assumes no specific form of production function (Coelli et al. 2005). Second, as reported by Battese et al. (2004), the use of SFA may not guarantee that the estimated meta-frontier envelops the estimated group frontiers, unless linear programming is utilized.

\section{Data}

The methodology outlined above is applied to construct a manufacturing sector metafrontier for Turkey. For this purpose the data covering the period between 1992 and 2001 are collected from the Turkish Statistical Institute (TURKSTAT) at the four digit level of the International Standard Industrial Classification (ISIC). According to this classification, we have 12 subsectors in the first group where the foreign affiliated firms operate. Foreign affiliated firms are private establishments with 20 or more employees and the share of foreign agents in equity equals at least $10 \%$ as categorized by TURKSTAT. The second group for the domestic firms contains 68 subsectors, hence the computation of meta-frontier is based on 80 subsectors $^{3}$. Due to data limitation we use one output and two inputs in the data envelopment analysis. Total value added produced by each sector is chosen as a proxy for output, whereas annual average number of paid workers and total horsepower of installed equipment are used as proxies for the labor and the capital respectively. Descriptive properties of the data are presented in Table 1. As for domestic firms, the minimum value added is created by the subsector "spinning, weaving and finishing textiles (3211)", whereas the maximum value added is also created by "cordage, rope and twine industries (3215)" as one of the subsector of the textile industry. On the other hand manufacture of paints, varnishes and lacquers (3521) and manufacture of motor vehicles (3843) have attained the highest and the lowest value added for foreign firms, respectively.

Table 1. Descriptive Properties of the Data in Logarithmic Values

\begin{tabular}{|c|c|c|c|c|}
\hline & & $\ln Q$ & $\ln L$ & $\ln K$ \\
\hline \multirow{4}{*}{ 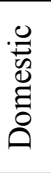 } & Mean & 18.514 & 9.553 & 12.007 \\
\hline & Std. Dev. & 19.293 & 9.961 & 12.664 \\
\hline & Min & 8.899 & 4.875 & 6.319 \\
\hline & Max & 21.944 & 12.016 & 14.838 \\
\hline \multirow{4}{*}{ 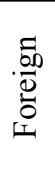 } & Mean & 18.432 & 8.536 & 10.708 \\
\hline & Std. Dev. & 19.174 & 8.800 & 11.011 \\
\hline & Min & 12.264 & 6.477 & 8.427 \\
\hline & Max & 20.986 & 10.275 & 12.607 \\
\hline
\end{tabular}

\footnotetext{
${ }^{3}$ For comparison purpose we only report the efficiency results of industries where foreign affiliated firms operate. The results of the other industries are not given here to conserve space but available upon request from the corresponding author.
} 


\section{Empirical Results}

In order to estimate technical efficiency and technology gap ratios using data envelopment analysis, we utilize the DEAP computer program developed by Coelli (1998). Average meta and group technical efficiency scores and technology gap ratios of domestic and foreign affiliated firms in the subsectors are reported in Table 2. To compare domestic and foreign affiliated subsectors also individually, the efficiency results of selected manufacturing subsectors are also presented in Table 3.

Table 2. Average Technical Efficiency and Technology Gap Ratios

\begin{tabular}{ccccccc}
\hline \multicolumn{2}{c}{ Average Technical Efficiency } & \multicolumn{2}{c}{ Technology Gap Ratio } \\
\hline \multicolumn{2}{c}{ Momestic } & $\begin{array}{c}\text { Foreign Affiliated } \\
\text { Firms }\end{array}$ & $\begin{array}{c}\text { Domestic } \\
\text { Firms }\end{array}$ & $\begin{array}{c}\text { Foreign } \\
\text { Affiliated } \\
\text { Firms }\end{array}$ \\
\hline 1992 & 0.8198 & 0.8503 & 0.8975 & 0.9258 & 0.9642 & 0.9695 \\
\hline 1993 & 0.8263 & 0.8373 & 0.9320 & 0.9415 & 0.9869 & 0.9899 \\
\hline 1994 & 0.8486 & 0.8752 & 0.9467 & 0.9469 & 0.9696 & 0.9997 \\
\hline 1995 & 0.8252 & 0.8345 & 0.9316 & 0.9478 & 0.9888 & 0.9829 \\
\hline 1996 & 0.8078 & 0.8234 & 0.9216 & 0.9300 & 0.9811 & 0.9910 \\
\hline 1997 & 0.8019 & 0.8119 & 0.9000 & 0.9377 & 0.9877 & 0.9598 \\
\hline 1998 & 0.8092 & 0.8144 & 0.8968 & 0.9282 & 0.9936 & 0.9662 \\
\hline 1999 & 0.8274 & 0.8287 & 0.9082 & 0.9394 & 0.9985 & 0.9667 \\
\hline 2000 & 0.8308 & 0.8308 & 0.9108 & 0.9428 & 1.0000 & 0.9661 \\
\hline 2001 & 0.8087 & 0.8123 & 0.9024 & 0.9121 & 0.9955 & 0.9894 \\
\hline Average & 0.8198 & 0.8503 & 0.8975 & 0.9258 & 0.9866 & 0.9781 \\
\hline
\end{tabular}

As it is presented in Table 2, technical efficiency scores of each group (domestic and foreign affiliated firms in the subsectors) show a stable pattern over the period. Foreign affiliated firms are generally found to be more efficient in terms of both meta and group technical efficiency. The evidence on group-technical efficiency scores clearly implies the superiority of foreign affiliated firms and they produce approximately $92.6 \%$ of the maximum level of output under the given group technology set. Although meta-frontier technical efficiencies found to be less than those of the group technical efficiencies, they support the findings obtained from group frontiers. Meta-technical efficiencies suggest that foreign affiliated firms are able to produce $89.8 \%$ of their potential output under the meta-technology set. 
Table 2 also reports the TGR's of foreign affiliated and domestic firms. In the first half of the analysis period, TGR's of the foreign affiliated firms are higher than those of domestic firms. However, domestic firms are closing the gap between the meta and group technology with the rise in TGR's especially after 1996 (see Fig. 2). When the whole period is taken into consideration, foreign affiliated firms have attained lower technology gap ratios. Firms operating in foreign affiliated subsectors, on average, produce only about $97.8 \%$ of the potential output given the available unrestricted meta-technology. However domestic firms are able to produce about $98.7 \%$ of their potential output.

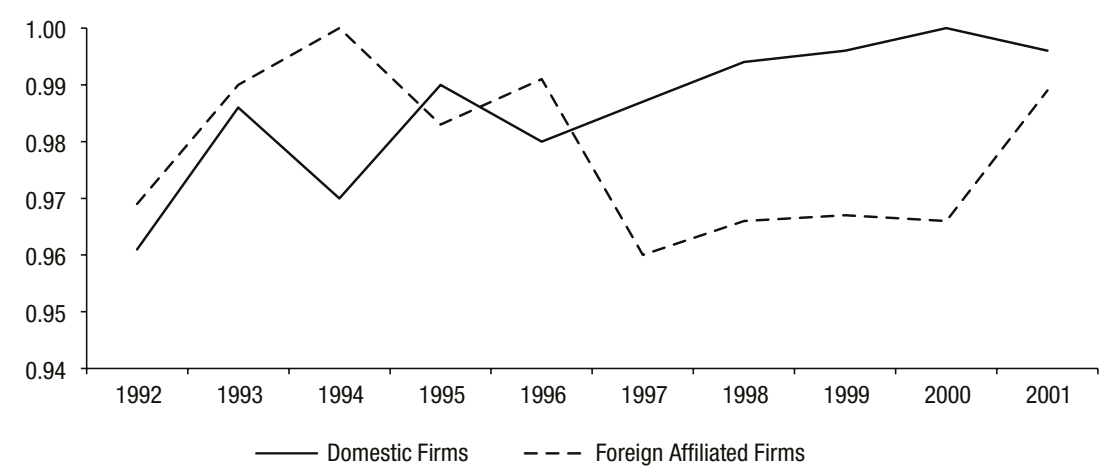

Fig. 2. Technology Gap Ratios of Domestic and Foreign Affiliated Firms

Individual technical efficiency scores with respect to group and meta-frontiers also confirm the superiority of foreign affiliated firms (see Table 3). Technical efficiency scores with respect to meta-frontier are ranging from 0.713 to 0.913 in domestic firms and they are less than those of foreign affiliated firms (see Table 3). Foreign affiliated firms operating in Tobacco (3140), Paints (3521), cleaning and cosmetics (3523) chemical (3529) and plastic products (3560) subsectors determine the meta-frontier at least in one year, i.e. the best input-output combinations are attained by these subsectors.

TGR's of the individual subsectors in Table 4 are also worth noting. The frontiers of domestic and foreign firms are tangent to the meta-frontier at least one time over the investigation period. Domestic firms operating in the tobacco industry have attained the highest TGR. This industry could produce about $99.9 \%$ of output that could be produced using the unrestricted meta-technology. The performance of this industry for foreign affiliated firms is found to be moderate. Although foreign affiliated firms have higher technology gap ratios in different subsectors, manufacture of paint, cleaning products, plastic and chemical products have attained the same TGR levels. However; the difference between domestic and foreign affiliated firms in terms of TGR's are less pronounced than those of meta-technical efficiencies. This evidence suggests that technological infrastructure may not be the main determinant in explaining productivity differences between domestic and foreign affiliated firms. 


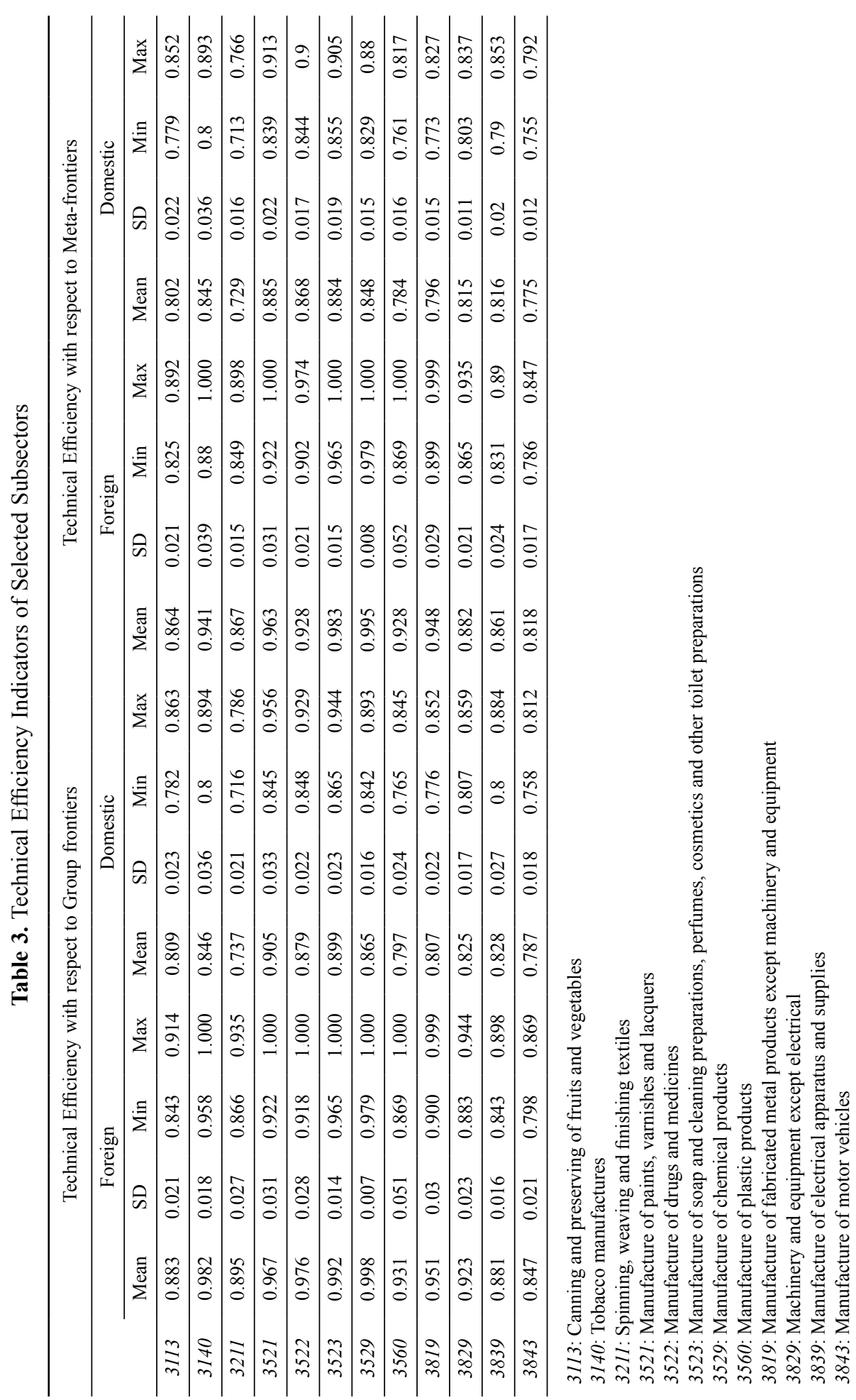


Table 4. Technology Gap Rations of Some Selected Subsectors

\begin{tabular}{ccccccccc}
\hline \multicolumn{7}{c}{ Technology Gap Ratio } \\
\hline \multicolumn{7}{c}{ Foreign } \\
\hline 3113 & $0.978(10)$ & 0.023 & 0.940 & 1.000 & $\mathbf{0 . 9 9 1 ( 8 )}$ & 0.008 & 0.973 & 1.000 \\
\hline 3140 & $0.959(5)$ & 0.027 & 0.911 & 1.000 & $\mathbf{0 . 9 9 9 ( 5 )}$ & 0.001 & 0.996 & 1.000 \\
\hline 3211 & $0.970(9)$ & 0.028 & 0.924 & 1.000 & $0.989(12)$ & 0.010 & 0.971 & 1.000 \\
\hline 3521 & $\mathbf{0 . 9 9 7 ( 3 )}$ & 0.008 & 0.975 & 1.000 & $0.979(1)$ & 0.017 & 0.948 & 1.000 \\
\hline 3522 & $0.952(6)$ & 0.028 & 0.908 & 1.000 & $0.987(3)$ & 0.012 & 0.968 & 1.000 \\
\hline 3523 & $0.992(2)$ & 0.012 & 0.965 & 1.000 & $0.983(2)$ & 0.017 & 0.953 & 1.000 \\
\hline 3529 & $\mathbf{0 . 9 9 7 ( 1 )}$ & 0.006 & 0.985 & 1.000 & $0.980(4)$ & 0.017 & 0.949 & 1.000 \\
\hline 3560 & $\mathbf{0 . 9 9 7 ( 7 )}$ & 0.006 & 0.982 & 1.000 & $0.985(10)$ & 0.013 & 0.962 & 1.000 \\
\hline 3819 & $\mathbf{0 . 9 9 7 ( 4 )}$ & 0.006 & 0.981 & 1.000 & $0.987(9)$ & 0.012 & 0.965 & 1.000 \\
\hline 3829 & $0.956(8)$ & 0.025 & 0.921 & 0.997 & $0.988(7)$ & 0.011 & 0.965 & 1.000 \\
\hline 3839 & $0.978(11)$ & 0.021 & 0.949 & 1.000 & $0.986(6)$ & 0.013 & 0.963 & 1.000 \\
\hline 3843 & $0.967(12)$ & 0.018 & 0.951 & 1.000 & $0.986(11)$ & 0.014 & 0.959 & 1.000 \\
\hline
\end{tabular}

Note: The numbers in parentheses represent the ranking of subsectors with respect to meta-frontier technical efficiencies. See Table 3 for the classification numbers of the subsectors.

Table 4 also suggests that the domestic firms with high efficiency scores have attained relatively low technology gap ratios. This means that technically efficient firms are in fact using the low level of technology. The manufacture of paints containing the most efficient firms in terms of meta-technical efficiency has attained the lowest technology gap ratio. However, tobacco manufacturing ranked in the fifth place according to meta-technical efficiency has attained the highest technology gap ratio among the other subsectors. These evidences indicate the existence of a negative relationship between the TGR's and technical efficiency of the firms in domestic subsectors. However the results do not indicate any significant relationship between the technical efficiency and TGR's of foreign affiliated firms ${ }^{4}$.

\section{Conclusions}

This paper aims to compare technical efficiencies of the foreign affiliated and domestic firms in Turkish manufacturing subsectors by employing meta-frontier approach introduced by Battese and Rao (2002). This approach allows us to take into consideration the

\footnotetext{
${ }^{4}$ In order to see the significance of the differences between TGR and TE of the domestic and foreign affiliated industries we conduct Spearman rank correlation tests. The correlation between TGR's and technical efficiency of the domestic industries indicates a highly negative relationship with -0.6848 and it is significant at 5 percent level. However the same statistic computed for the foreign affiliated industries are found to be insignificant.
} 
heterogeneity in terms of technology level and helps us to construct a technology gap ratio to compare the relative efficiency levels of domestic and foreign affiliated firms.

We find that technical efficiency ratios of foreign affiliated firms are higher than domestic firms, and show a stable pattern during the period subject to the analysis. However, technology gap ratios of domestic firms show that domestic firms are closing the gap between the global technologies, especially after 1996. Unlike domestic firms, we see an opposite trend for foreign affiliated firms, of which the technology gap increases.

The meta-technical efficiencies and TGR's indicate the existence of a negative relationship between efficiency and gap ratios for domestic firms. However we do not find such a significant relationship for foreign affiliated firms. Low level of TGR in domestic firms can be attributed to low level of $R \& D$ and the absence of technology spillovers between domestic and foreign affiliated firms. These results confirm the previous findings that there is no horizontal FDI spillover to the domestic firms in Turkey (see Lenger, Taymaz 2006). The decline in TGR's observed in foreign affiliated firms can be also adhered to the fact that the amount of R\&D expenditures of foreign affiliated firms has been declining in the recent years. According to TURKSTAT data, the total amount of R\&D expenditures in manufacturing industries show an increasing trend until 1999, but nearly decreased by half in 2001 due to the financial crisis in November 2000-February 2001. When the shares of domestic and foreign affiliated firms are compared, except for 1998 domestic firms allocated more resources on R\&D during the period subject to analysis (Karacuka, Catik 2011). UNCTAD (2005) also reports that Turkey is ranked as one of the least attractive countries in terms of R\&D expenditures of TNCs, and the amount of R\&D expenditures of foreign affiliated firms has been declining in the recent years. The absence of a significant relationship between TGR and technical efficiency in foreign affiliated firms should be investigated in more detail as the firm level data become available.

\section{References}

Balasubramanyam, V. N.; Salisu, M.; Dapsoford, D. 1996. Foreign direct investment and growth in EP and IS countries, Economic Journal 106: 92-105. http://dx.doi.org/10.2307/2234933

Battese, G.; Rao, D. S. P. 2002. Technology gap, efficiency and stochastic meta-frontier function, International Journal of Business and Economics 2: 87-93.

Battese, G.; Rao, D. S. P.; O’Donnell, C. 2004. A meta-frontier production function for calculation of technical efficiencies and technology gaps for firms operating under different technologies, Journal of Productivity Analysis 21: 91-103. http://dx.doi.org/10.1023/B:PROD.0000012454.06094.29

Blomström, M.; Kokko, A. 1998. Multinational corporations and spillovers, Journal of Economic Surveys 12: 247-277. http://dx.doi.org/10.1111/1467-6419.00056

Blomström, M.; Kokko, A. 2003. The economics of foreign direct investment incentives, NBER Working Paper Series No. w9489.

Blomstörm, M.; Lipsey, R. E.; Zejan, M. 1992. What explains developing country growth?, NBER Working Paper Series No. 4132.

Bayyurt, N.; Duzu, G. 2008. Performance measurement of Turkish and Chinese manufacturing firms: a comparative analysis, Eurasian Journal of Business and Economics 2: 71-83. 
Borensztein, E.; De Gregorio, J.; Lee, J-W. 1998. How does foreign direct investment affect economic growth?, Journal of International Economics, 45: 115-135.

Carkovic, M.; Levine, R. 2002. Does foreign direct investment accelerate economic growth?. Working Paper. University of Minnesota Department of Finance. Available from Internet: www// ssrn.com/abstract $=314924$.

Coelli, T. A. 1998. Guide to DEAP Version 2.1: A Data Envelopment Analysis (Computer Program). CEPA Working Paper 96/08, UNE, Australia.

Coelli, T.; Rao, D. S. P.; O’Donnell, C.; Battese, G. 2005. An introduction to efficiency and productivity analysis. $2^{\text {nd }}$ ed. New York: Springer-Verlag.

Dumludag, D. 2009. An analysis of the determinants of foreign direct investment in Turkey: the role of the institutional context, Journal of Business Economics and Management 10(1): 15-30. http://dx.doi.org/10.3846/1611-1699.2009.10.15-30

Görg, H.; Strobl, E. 2001. Multinational companies and productivity spillovers: a meta-analysis, Economic Journal 111(475): 723-739. http://dx.doi.org/10.1111/1468-0297.00669

Karaçuka, M.; Catik, A. 2012. A spatial approach to measure productivity spillovers of foreign affiliated firms in Turkish manufacturing industries, The Journal of Developing Areas 46(2): 65-83. http://dx.doi.org/10.1353/jda.2012.0039

Karadağ, M.; Deliktaş, E.; Önder, Ö. 2004. The effects of public capital on private sector performance in Turkish regional manufacturing industries, European Planning Studies 8: 1145-1155. http://dx.doi.org/10.1111/1468-0297.00669

Karadă̆, M.; Önder, Ö.; Deliktaş, E. 2002. TFP change in the Turkish manufacturing industry in the selected provinces: 1990-1998, in $6^{\text {th }}$ METU International Conference in Economics, September 11-12, 2002, Ankara.

Karadă̆, M.; Önder, Ö; Deliktaş, E. 2005. Growth of factor productivity in the Turkish manufacturing industry at provincial levels, Regional Studies 39(2): 213-223.

http://dx.doi.org/10.1080/003434005200060007

Köymen, S.; Sayek, S. 2009. The role of human capital in productivity spillovers from FDI: an empirical analysis on Turkish manufacturing firms. Workshop papers. ESRC-ITU and University of Nottingham.

Krueger, A. O.; Tuncer, B. 1982. Growth of factor productivity in Turkish manufacturing subsectors, Journal of Development Economics 11: 307-325.

http://dx.doi.org/10.1016/0304-3878(82)90009-8

Lall, S. 1978. Transnational, domestic enterprises and industrial structure in host LDCs: a survey, Oxford Economic Papers 30(2): 217-248.

Lall, S. 1997. Investment, technology and international competitiveness, in J. H. Dunning, K. A. Hamdani (Eds.). The new globalism and developing countries. Tokyo: UNU Press.

Lenger, A.; Taymaz, E. 2006. To innovate or to transfer? A study on spillovers and foreign firms in Turkey, Journal of Evolutionary Economics 16: 137-153.

http://dx.doi.org/10.1007/s00191-005-0002-4

O'Donnell, C.; Rao, D. S. P.; Battese, G. 2008. Meta-frontier frameworks for the study of firm level efficiencies and technology ratios, Empirical Economics 34: 231-255.

http://dx.doi.org/10.1007/s00181-007-0119-4

Önder, Ö.; Deliktaş, E.; Lenger, A. 2003. Efficiency in the manufacturing industry of selected provinces in Turkey: a stochastic frontier analysis, Emerging Markets Finance and Trade 39(2): 98-113.

Rambaldi, A.; Rao, D. S. P.; Dolan, D. 2007. Measuring productivity growth performance using meta-frontiers with applications to regional productivity growth analysis in a global context, in Australasian Meeting of The Econometric Society (ESAM07), July 3-6, 2007, Brisbane. 
Ramírez, M. D. 2006. Does foreign direct investment enhance private capital formation in Latin America? A pooled analysis for the 1981-2000 period, The Journal of Developing Areas 40(1): 81-97.

Rao, D. S. P.; O’Donnell, C.; Battese, G. 2003. Meta-frontier functions for the study of interregional productivity differences, CEPA Working Paper Series 01/2003. School of Economics. University of Queensland.

Taymaz, E.; Saatçi, G. 1997. Technical change and efficiency in Turkish manufacturing subsectors, Journal of Productivity Analysis 8: 461-475. http://dx.doi.org/10.1023/A:1007796311574

UNCTAD. 1999. World Investment Report 1999. New York: United Nations Publication.

UNCTAD. 2005. World Investment Report 2005. New York: United Nations Publication.

Wijweera, A.; Villano, R.; Dollery, B. 2010. Economic growth and FDI inflows: a stochastic frontier analysis, The Journal of Developing Areas 43(2): 143-158.

http://dx.doi.org/10.1353/jda.0.0059

Yılmazkuday, H. 2009. Productivity cycles in public and private manufacturing sectors: evidence from Turkey, International Journal of Applied Economics 6: 21-40.

Zaim, O.; Taskin, F. 1997. The comparative performance of the public enterprise sector in Turkey: a malmquist productivity index approach, Journal of Comparative Economics 25: 129-157. http://dx.doi.org/10.1006/jcec.1997.1459

Halil TUNCA is a Research Assistant and PhD student in Economics at Ege University, Turkey. His research interests are mainly based on the measurement of productivity using alternative estimation methods.

Mehmet KARAÇUKA is an Assistant Professor at Ege University, Turkey, with PhD in Economics, and he is teaching Microeconomics and Applied Econometrics. His research interests are Applied Econometric Methods and Industrial Organization. He has written in cited journals like Journal of Telecommunications Policy, Applied Economics Letters, The Journal of Developing Areas; while he has been reviewer in different national and international journals such as The Journal of Developing Areas, The Service Industries Journal, and Applied Economics.

A. Nazif ÇATIK is an Assistant Professor at Ege University, Turkey, with PhD. His scientific interests are related to the nonlinear analysis of macro data and time series. He has written in cited and indexed journals like Emerging Markets Finance and Trade, Applied Economics Letters, The Journal of Developing Areas, Economics Bulletin, while he has been reviewer in various journals such as METU Development Studies, Journal of Economic Studies, He has published papers in national and international conferences on time series analysis and robust statistics. 